\title{
Vozes do silêncio: considerações sobre a linguagem dos cativos no Brasil
}

\author{
Florence Carboni ${ }^{1}$
}

Résumé: Après avoir mis l'accent et expliqué le manque relatif, dans les sciences du langage, d'études sur la communication verbale et les formations discursives des travailleurs asservis et de leurs descendants au Brésil, cet article présente une analyse succincte des dramatiques pertes langagières et discursives des communautés esclaves, à partir de la catégorie des repertoires linguistiques, et propose quelques pistes pour la récupération d'aspects linguistico-idéologiques propres à ces communautés.

Mots-clefs: Esclavage, répertoire linguistique, centralisation linguistique

\section{Introdução}

A história e sobretudo a história linguística do Brasil são apresentadas como intimamente relacionadas a uma entidade abstrata chamada "língua portuguesa", semi-natural, intrínseca à natureza dos brasileiros. Faz-se abstração do fato desta língua ter chegado de Portugal já com variantes regionais e sociais. De ter sido, nos dois países, a única que conheceu instrumentos linguísticos de gramatização e dicionarização. De ter conhecido uma progressiva e exclusiva legitimação através da associação a discursos ideológicos em esferas institucionalizadas da vida científica e artística e no âmbito do poder. De tais processos terem sido acompanhados do absoluto silenciamento de amplos setores da população, falantes de outras línguas.

O Brasil não tem exclusividade neste fenômeno. No ensaio "O discurso no romance", de 1934, o soviético Mikhaïl Bakhtin fala das "tendências centralizadoras da vida da linguagem", que existem na imensa maioria dos Estados-nação modernos, onde qualquer referência a outros códigos praticados por certos setores da população, no passado e ou no presente, é geralmente acessória, servindo apenas para explicar a evolução daquele código linguístico, na sua forma padrão.( BAKHTINE, 1978, p.89) ${ }^{2}$

Em A unidade lingüística no Brasil, de 1979, o linguista Sílvio Elia defende que, na communis opinio brasileira, existe a convicção da "notável unidade da língua portuguesa no Brasil". (ELIA, 1979, p.12; 32 et seq.) Tal idéia já fora evidenciada pelo gramático Serafim da Silva Neto quando afirmava, em Introdução ao estudo da língua portuguesa no Brasil, de 1951, que "os portugueses da Europa e seus filhos falavam um português de notável unidade, enquanto os aborígines, os negros e os mestiços se entendiam num crioulo" e que, à medida "que se ia firmando a civilização, o português, graças ao seu prestígio de língua dos colonizadores e de língua literária, foi-se irradiando". (SILVA NETO, 1951, p.10-11)

Para esses dois grandes intelectuais brasileiros, entre os principais reprodutores e fomentadores do discurso linguístico dominante, a unidade da língua no Brasil daria-se paralelamente ao processo de difusão da civilização dos "brancos, certos de sua superioridade" [sic] contra a barbárie de outros povos - "selvagens do interior" [sic], "mestiços" e "negros", todos em atrasado estágio de civilização - eles se entenderiam através de falares híbridos e aproximativos, de certa forma indignos de pertencer à história linguística da nação brasileira. (Ibid, p.32 et seq.)

É muito difusa e aparentemente inquestionável a idéia de que uma língua comum única é indispensável para garantir a intercompreensão no seio de uma população nacional. Em geral passa despercebido que, em sociedades complexas, toda língua supostamente comum foi gerada e constituída "pelas forças reais do devir verbal e ideológico de certos grupos sociais precisos" e representa "a expressão teórica dessas forças eficazes, criadoras da vida da linguagem", como propõe Mikhaïl Bakhtin, na obra apenas citada. Além disso, concepções linguísticas unitaristas tendem a ver a língua comum - sistema formal - como capaz de garantir "um mínimo de compreensão na comunicação corrente". Não como "uma linguagem ideologicamente saturada, como uma concepção de mundo, até mesmo como uma opinião concreta, como algo capaz de

\footnotetext{
${ }^{1}$ Um agradecimento ao historiador Mário Maestri pela leitura criteriosa do artigo e suas valiosas considerações a respeito da parte histórica do mesmo.

${ }^{2}$. São nossas todas as traduções de trechos de obras estrangeiras.
} 
garantir um máximo de compreensão mútua, em todas as esferas da comunicação ideológica". (BAKHTINE, Op. cit., p.95)

\section{Guerra linguística}

A categoria "língua única", expressão teórica dos processos históricos de unificação e centralização sóciopolíticos e culturais, apesar de "real enquanto força que transcende o plurilinguismo, que lhe opõe certas barreiras", deve, no entanto, confrontar-se constantemente às forças centrífugas da comunicação verbal. (Ibidem) Isto porque a língua nunca é "algo uniforme, homogêneo e monolítico: não é uma; nela, há outras línguas, como matrizes, como sobrevivências, como alternativas descartadas, como possibilidades latentes. Outras línguas com as quais a primeira encontra-se em relação de 'compromisso', de 'conflito', de 'absorvimento', de 'intercâmbio', etc.", como assinala o linguista italiano Augusto Ponzio, em Tra semiotica e letteratura, de 2003. (PONZIO, 2003, p.67)

As tendências centralizadoras da vida da linguagem não deixam "espaço à dialogização, determinada pelo conflito dos pontos de vista sociolingüísticos, ressonâncias das diversas vozes sociais." (BAKHTINE, Op. Cit., p.89). O corolário é que as concepções linguísticas monológicas que consideram essencial a unidade linguística de uma nação e de um povo, através da língua nacional, tendem a atribuir ao "signo verbal o caráter de mero instrumento de representação e expressão". Tratam a palavra como algo que apenas "denota, nomeia [...], expressa seu objeto", que "soa como se fosse palavra direta e imediatamente intencional" (PONZIO, Op. Cit., p.65).

Até há poucos anos, as disciplinas de Língua Portuguesa e, em geral, os cursos de Letras das universidades brasileiras tendiam a se despreocupar com tudo que não fosse a variedade padrão da língua nacional. Tendiam a desconsiderar as práticas linguísticas das comunidades aloglotas presentes no território brasileiro e as variedades do português efetivamente praticadas, no passado e no presente, pela população de todo o país e de todas as camadas sociais. Nos últimos tempos, essa realidade tem mudado com a realização e difusão de investigações de campo e reflexões teóricas sobre, por exemplo, a variação social e regional do português; a estigmatização escolar dos "falares populares"; a discriminação das línguas e dialetos da imigração e sua interação com o português; as formações discursivas antagônicas ao discurso dominante, etc.

Mesmo assim, é forçoso constatar que, no Brasil, ao lado da profusão de estudos dialetológicos, sociolinguísticos, discursivos etc. sobre a imigração européia e, em menor quantidade, sobre as línguas americanas, são raras as pesquisas linguísticas sobre os trabalhadores escravizados, apesar de representarem uma proporção mais do que considerável da população brasileira do passado.

Há poucos trabalhos científicos sobre as línguas que os cativos falavam ao serem capturados na África, forçados a subir nos tumbeiros, desembarcados no Brasil; sobre as soluções linguageiras que desenvolveram para sobreviver no cativeiro; sobre as variedades do português, hoje dominantes, nas quais os cativos, libertos, fujões, quilombolas deixaram fortes marcas; sobre as formações discursivas dominantes nos campos, cidades, mocambos, etc., produzidas pelas comunidades escravizadas.

O presente trabalho parte do pressuposto que muitos dos ainda demasiadamente raros estudos relativos às línguas que os navios negreiros trouxeram para o Brasil - e suas relações de conflito, intercâmbio e interinfluência com o português brasileiro - apresentam um viés metodológico fortemente ligado à dialetologia e à sociolinguistica variacionista e quantitativa. ${ }^{3} \mathrm{Em}$ geral, tais estudos focalizam-se na observação de elementos formais - fonético-fonológicos, morfo-sintáticos, lexicais - e tendem a se despreocupar com os aspectos semânticos e discursivos. Tendem a não explorar os fenômenos específicos ao discurso e à orientação dialógica entre as tantas vozes estrangeiras dentro da suposta língua nacional que representa o português definido como padrão.

A presente reflexão pretende explorar possíveis caminhos teóricos e metodológicos para o resgate possível das línguas e dos discursos dos trabalhadores africanos e afro-descendentes, força de trabalho hegemônica no passado brasileiro.

\section{CATIVOS DE FERRO}

\footnotetext{
${ }^{3}$ Ver, por exemplo, o excelente estudo de Sônia Queiroz, Pé preto no barro brando. A língua dos negros de Tabatinga. Belo Horizonte: Editora UFMG, 1998.
} 
Até 1888, o modo de produção escravista colonial permaneceu dominante e marcou de forma profunda e essencial a história do Brasil. ${ }^{4} \mathrm{Na}$ obra L'esclavage au Brésil, de 1991, o historiador riograndense Mário Maestri lembra que o "Brasil foi o país das Américas que desenvolveu mais o sistema escravista"(MAESTRI, 1991, p.41). As populações americanas foram escravizadas nos primeiros anos após a chamada descoberta, mas já em 1549, os portugueses introduziam no Brasil trabalhadores escravizados arrancados da África, talvez "pelo conhecimento prévio da capacidade de trabalho dos negros e da maior facilidade de sua submissão em habitat estranho, ao contrário dos ameríndios, cuja escravização esbarrava com a resistência tribal em território nativo", como propõe o historiador baiano Jacob Gorender, em O escravismo colonial, de 1985. (GORENDER, Op.cit. p.122).

Segundo Gorender, já "na primeira metade do século 16, o trabalhador escravizado africano constituía "a força de trabalho fundamental das regiões de economia plantacionista próspera, continuando o índio o recurso preponderante ou quase único das regiões pobres, onde a produção de lucrativos gêneros de exportação não vingava" (Ibid., p.125). A partir do século 17, a escravidão no Brasil tornou-se essencialmente negroafricana. Calcula-se que, em cerca de três séculos, de 1560 a 1850, "possivelmente um número superior a 5 milhões de homens, mulheres e crianças reduzidos à escravidão, foram arrancados do Continente Negro e desembarcados" nas praias do Brasil. (MAESTRI 1986, p.82)

Nos séculos 16 e 17, no primeiro período colonial, quando do chamado Ciclo do Açúcar, os portugueses e luso-brasileiros reduziram à escravidão e trouxeram para o Brasil sobretudo habitantes do litoral da chamada faixa sudanesa, do golfo da Guiné e do litoral da África Central atlântica. Nos séculos 17 e 18, foram os territórios correspondentes à atual Angola que constituíram a principal reserva de caça dos portugueses escravistas, que, a seguir, no século 19, estenderam o comércio medonho aos territórios do atual Moçambique. Para além desses aspectos nacionais, é fundamental compreendermos que, por mais de três séculos, o trabalhador escravizado constituiu o principal pilar do desenvolvimento econômico brasileiro.

Segundo Mário Maestri, durante este longo período, "as principais atividades econômicas e comerciais do país basearam-se no trabalho dos negros escravizados; é o caso da produção açucareira, da mineração, da cultura do algodão, do arroz, do café, etc. As atividades anexas, como os transportes, a pecuária, a agricultura de subsistência, etc. dependiam também em maior ou menor proporção desta forma de trabalho." (MAESTRI, Op.cit., p.122) Esse contexto econômico determinou que, desde então, o Brasil contasse com uma significativa população escravizada, africana e afro-descendente. Segundo o censo de 1872, em uma população total de cerca de dez milhões de habitantes, o Brasil contava 5.792 .000 "escravos e livres, de origem ou ascendência africana (58\% de negros e mulatos na população total)". (GORENDER, Op.Cit. p.325).

A importância numérica da população africana e afro-descendente escravizada no Brasil e sua fundamental contribuição em todos os aspectos da vida econômico-social marcaram fortemente muitas práticas culturais da população brasileira e sua ideologia da vida, que, para o grande intelectual soviético Valentin Volochinov, representa o conjunto das experiências de vida de uma comunidade, que reflete e refrata a realidade social objetiva e que dá um significado a cada uma das ações e a cada um dos estados de consciência dos seus membros:

Do oceano instável e mutável da ideologia da vida, gradativamente afloram as inúmeras ilhas e os continentes dos sistemas ideológicos: da ciência, da arte, da filosofia, das teorias políticas [...]. Por sua vez, estes sistemas tem uma fortíssima influência retroativa sobre a ideologia da vida, dando-lhe frequentemente o tom dominante. Ao mesmo tempo, estes produtos ideológicos em formação conservam sempre um vínculo com a ideologia da vida, nutrindo-se de sua seiva, e, separados dela, definham e morrem. ${ }^{5}$

As determinações do modo de produção escravista colonial explicam tendencialmente, por exemplo, a extrema fragilidade do campesinato brasileiro. Por campesinato, entendemos uma classe social dedicada a uma produção agrícola e artesanal autônoma, apoiada essencialmente na divisão familiar do trabalho, onde a produção é orientada à satisfação das necessidades familiares de subsistência e à mercantilização, a fim de obter recursos monetários necessários para a compra de outros produtos e serviços. Uma debilidade da classe camponesa no Brasil que não se deve apenas à escravidão, mas também ao tipo de organização social

\footnotetext{
${ }^{4}$ Ver. GORENDER, J. O escravismo colonial. $4^{\mathrm{a}}$ ed. rev. e ampl. São Paulo: Ática, 1985; CARDOSO, C.F. El modo de producción esclavista colonial en América. In ASSADOURIAN, C.S. et al. Modos de producción en América Latina. Buenos Aires: Siglo XXI, 1973.

${ }^{5}$ Ver, entre outros, o artigo, assinado por VOLOCHINOV, "Stilistika chudožestvennoj reči", publicado em italiano com o título "Stilistica letteraria", no volume organizado por PONZIO, A., Linguaggio e Letteratura, Roma: Meltemi, 2003, p. 93 et seq. Organon, Porto Alegre, $n^{\circ}$ 47, julho-dezembro, 2009, p.85-1 27
} 
dominante no território brasílico no momento da chamada descoberta, onde inexistiam formas de produção agrícola avançadas. ${ }^{6}$

Por sua vez, a fragilidade do campesinato e o caráter escravista dominante da produção rural na antiga formação social brasileira determinaram tendencialmente a frágil disputa pela terra, quando da Abolição, quando os cativos lutaram, essencialmente, pela liberdade civil. Este fenômeno histórico contribuiu para que as classes dominantes brasileiras conseguissem até hoje evitar uma reforma agrária digna do nome. Ajuda a compreender igualmente a facilidade com a qual é difundido e aceito por grande parte da população brasileira o discurso dominante, reprovador e criminalizante, sobre os movimentos que reivindicam uma distribuição mais justa da terra no Brasil, formados inicialmente sobretudo por descendentes de colonos-camponeses europeus imigrados no Brasil no final do século 19.

O modo de produção escravista colonial que dominou o Brasil por mais de três séculos deixou vestígios na própria maneira como são concebidas, ainda hoje, as moradias da classe média brasileira, sobretudo urbana, com o imprescindível quarto de empregada, de dimensões comumente inadequadas ao ser humano. Ou na despreocupação com a cozinha, geralmente pequena, pouco iluminada, situada ao lado da área de serviço, na parte menos nobre da casa, contrariamente à tipologia de moradia dominante na Europa, fortemente influenciada pelo mundo camponês, onde ela era o centro do convívio familiar. ${ }^{7}$

Sempre no campo arquitetônico, podemos igualmente identificar a escravatura como responsável pelo fato da significativa presença de cativos, provenientes de diversas regiões do continente africano, não ter deixado gravadas na moradia brasileira suas tão variadas técnicas de construção, suas tradições arquitetônicas, seus gostos e valores estéticos. O contrário do que aconteceu nas regiões e cidades com forte afluxo de imigração européia ou asiática - região colonial italiana e alemã do Rio Grande do Sul; bairros italianos e japoneses em São Paulo ou Curitiba, etc.

Nessas regiões e cidades, a arquitetura tendeu a manter ou reinventar certas características formais, materiais e semânticas dos países de origem dos imigrantes, apesar deles terem sido imensamente menos numerosos do que os trabalhadores escravizados africanos transplantados à força para o Brasil. Neste, como em outros inúmeros aspectos da cultura material e imaterial brasileira, a presença dos africanos escravizados foi condenada a permanecer fortemente silenciosa. As exceções relativas seriam a música, a religião e a culinária, sobretudo em certas regiões do Brasil.

\section{O APAGAMENTO... "PELO MÊDO DE COMPROMETER NOSSA PRECÁRIA BRANQUIDADE"}

Apesar do modo de produção escravista colonial ter tido uma importância capital na formação social brasileira e, portanto, ter determinado de modo essencial as formações ideológicas, os saberes, as práticas culturais e, em última instância, as consciências individuais dos brasileiros, durante a escravidão e após a Abolição, sabemos pouquíssimo sobre as línguas, as modalidades da interação verbal, as formas de pensar e de ver o mundo dos trabalhadores escravizados, dos quilombolas, dos escravos fujões, dos rebelados, dos libertos. Os homens e as mulheres escravizados do passado, objetos da lírica de Castro Alves e das gravuras de Rugendas, que labutavam nos mais diversos ofícios e produziram a riqueza usufruída pelas classes dominantes de Portugal, do Brasil e da Europa, sem jamais terem se aproveitado substancialmente dela, não dialogam verdadeiramente com a população brasileira atual, nem mesmo com a população afro-descendente, que não raro tende a preferir buscar suas raízes na África do que no eito e na senzala, verdadeiros cadinhos da formação social brasileira.

São muitas as razões desse apagamento de parte essencial da história do Brasil. Por um lado, "a necessidade de justificar a dura exploração do produtor determinava a visão que o escravizador tinha do escravizado. O proprietário via o africano como ser primário, incapaz de compreender, apreender e comportar-se como homem civil. Um ente que necessitava ser permanentemente feitorizado sob a ameaça do castigo." (MAESTRI, 2004, p.192-209). O próprio imperador do Brasil, Pedro II, era adepto das teorias supostamente científicas sobre as diferenças raciais, então em moda na Europa imperialista. Ao propor a incapacidade das nações povoadas de negros e mestiços de atingir a civilização, tais teorias lançavam um

\footnotetext{
${ }^{6}$ Ver MAESTRI, M. A aldeia ausente. Índios, caboclos, cativos, quilombolas, moradores e imigrantes na formação da classe camponesa brasileira. In: STEDILE, J. [Org]. A questão agrária no Brasil. São Paulo: Expressão Popular, 2005, v.2, p. 217-277.

${ }^{7}$ Ver REIS FILHO, N.G. Quadro da arquitetura no Brasil. 6 ed. São Paulo: Perspectiva, 1987 e LEMOS, C.A.C. A casa brasileira. São Paulo: Contexto, 1989.

${ }^{8}$ Expressão utilizada porDA MATA MACHADO FILHO, A. O negro e o garimpo em Minas Gerais. Rio de Janeiro: Civilização brasileira, 1964, p.59. 
anátema sobre o futuro do Brasil. Na pós-República, para muitos, o remédio seria branquear a população brasileira, seja nos fatos, seja no imaginário, favorecendo a entrada de imigrantes europeus e abstraindo a população afro-descendente da construção das representações coletivas. ${ }^{9}$

Por outro lado, o fato de que "fontes para o estudo da escravidão foram geralmente produzidas por setores sociais interessados na permanência do escravismo" contribuiu para que a visão dos escravizadores fosse retomada e legitimada nos trabalhos de intelectuais de prestígio, difundindo-se, através da literatura, da escola, da mídia, etc. a toda a população brasileira, não apenas "branca", dificultando a necessidade de se colocar o negro escravizado como grande demiurgo da nação, na pré-Abolição (MAESTRI, 1988, p.9). Um negro visto, ao contrário, como ser primário e boçal e considerado mercadoria por mais de três séculos.

Mesmo hoje, mais de cento e vinte anos após o fim do cativeiro, parte da classe dominante do Brasil, herdeira sociológica dos setores escravocratas, através de seus intelectuais orgânicos, manipula as representações do passado escravista. Não podendo se livrar dessa lembrança comprometedora, esforça-se para apresentar, por um lado, a história da escravidão como apenas uma página do passado do Brasil, e não como seu elemento conformador, e, por outro, como instituição branda, onde existiria quase uma identidade de interesses entre escravizadores e escravizados. ${ }^{10}$

Tal revisionismo histórico, construído minuciosamente em parte da academia e na mídia, favorece um imaginário coletivo em que a participação do trabalhador africano e afro-descendente submetido à escravidão seja fortemente relativizada e abrandada, absolvendo ou justificando de certo modo as classes escravizadoras. Permite que se mantenha um véu sobre os sentimentos profundos dos cativos em relação aos seus proprietários e feitores e em relação à própria escravidão. Cria as condições para que a população brasileira continue desconhecendo os verdadeiros sofrimentos, as aspirações e sobretudo as necessidades daqueles homens, mulheres, jovens e velhos, recém-chegados da África ou nascidos no Brasil. Em História do negro brasileiro, de 1989, o sociólogo e líder negro Clóvis Moura lembra haver até mesmo uma tendência a diminuir o número de africanos importados pelo tráfico, também parte do esforço de historiadores em branquear a população brasileira (MOURA, 1989, p.9).

\section{O PLURILINGUISMO DO BRASIL COLONIAL E IMPERIAL}

Os falares tupis descritos pelos jesuítas José de Anchieta, em meados do Quinhentos, em A arte da gramática da língua mais usada na costa do Brasil; Luís Figueira, em 1621, em Arte da língua brasílica; e Luís Mamiami, em 1699, em Arte de gramática da língua brasílica da nação cariri, eram apenas algumas entre as inúmeras línguas - locais, regionais, francas - praticadas pelos mais de seiscentos mil nativos, senhores das terras dos quais os portugueses começaram a apoderar-se a partir de 1500. (ELIA, Op. Cit., p.37 et seq.) Os especialistas estimam que, no momento da chamada descoberta, haveria cerca de 1.200 línguas no território correspondente ao Brasil atual. (BORGES, \& HORTA NUNES, 1998, p.52).

Para difundirem inicialmente a religião e os valores dos colonizadores, os jesuítas aprenderam a se comunicar nas línguas e coinés nativas. Em carta ao superior Simão Rodrigues de Azevedo, o padre Manuel da Nóbrega informava que os religiosos procuravam "saber a língua deles" e "tirar em sua língua as orações e algumas práticas de Nosso Senhor", deixando explícita sua visão preconceituosa ao afirmar que "não posso achar língua que o saiba dizer, são eles tão brutos que nem vocabulário têm". ${ }^{11}$ Não apenas no início da colonização, muitos portugueses teriam também aprendido e praticado línguas e coinés, sobretudo tupis, por necessidade ou, em alguns casos, por escolha, como mostra o linguista Serafim da Silva Neto: "[...] brancos e luso-descendentes [...], decaídos, se incorporaram às camadas ínfimas [sic] da população" (DA SILVA NETO, S. Op. Cit., p.136).

Citando Teodoro Sampaio, Serafim da Silva Neto propõe que, na imensa capitania de São Paulo, as "bandeiras quase que só falavam o tupi. E se, por toda a parte onde penetravam, estendiam os domínios de Portugal, não lhe propagavam, todavia, a língua, a qual só mais tarde se introduziu com o progresso da

\footnotetext{
${ }^{9}$ Ver, entre outros, RAEDERS, G. O conde de Gobineau no Brasil: o inimigo cordial do Brasil. Rio de Janeiro: Paz e Terra, 1988; SCHWARCZ, L.M. O espetáculo das raças: cientistas, instituições e questões raciais no Brasil, 1870-1930. São Paulo: Companhia das Letras, 1993.

${ }^{10}$ Ver, entre outros, GORENDER, J. A escravidão reabilitada. São Paulo: Ática, 1990; MATTOSO, K.de Q. Ser escravo no Brasil. São Paulo: Brasiliense, 1982; SLENES, R.W. Na senzala, uma flor. Esperanças e recordações na formação da família escrava - Brasil Sudeste, século XIX, Rio de Janeiro: Nova Fronteira, 1999.

${ }^{11}$ Citado por NISKIER, A. Educação brasileira. 500 anos de história. 1500-2000. São Paulo: Melhoramentos, 1989, p.44. Organon, Porto Alegre, no 47, julho-dezembro, 2009, p.85-1 27
} 
administração, com o comércio, e os melhoramentos"(Ibid., p.60). Citando o mesmo autor, Sílvio Elia especifica que as regiões que se iam descobrindo recebiam "um nome tupi [...] e o conservavam pelo tempo adiante, ainda que nelas jamais tivesse habitado uma tribo da raça tupi. E assim é que, no Planalto Central, onde dominam povos de outras etnias, as denominações dos vales, rios e montanhas e até das povoações são pela maior parte da língua geral." (ELIA, S. Op. Cit., p.151).

O caráter plurilingue do Brasil de então ficou registrado no fato de o cabo-de-guerra paulista Domingos Jorge Velho, também responsável, com seus tupis e mamelucos, pelo esforço militar que vergou a confederação do quilombo de Palmares, em 1695, expressar-se "mais à vontade na língua geral, tanto assim que se fazia acompanhar de um intérprete" quando devia entrar em contato com as autoridades administrativas coloniais lusitanas(Ibid., p.153).Para a lingüísta Bethania Mariani, em Colonização lingüística, de 2004, "fosse chamado de mameluco, bandeirante, paulista ou simplesmente 'brasileiro', esse sujeito outro que se constitui no paradoxal jogo de confrontos e alianças com os povos indígenas, irá usar no seu cotidiano ora a língua brasílica, ora uma 'língua portuguesa' outra, igual no nome, porém já diferente da existente em Portugal"(MARIANI, 2004, p.55).

No território correspondente ao atual Maranhão, onde, inicialmente, a Coroa portuguesa delegou fortemente a ocupação territorial às missões religiosas, outra língua geral, com forte componente tapuia, mas com inúmeras variantes, permaneceu língua semi-oficial até a proibição pombalina, em meados do Setecentos (BORGES, \& HORTA NUNES, Op. Cit., p.56). As línguas gerais jesuíticas utilizadas pelas populações envolvidas na colonização não teriam sido únicas. Tudo indica que outras línguas e coinés - aruaque, jê, caribe, etc. - conheceram também um uso difuso durante a Colônia, apesar de discriminadas em relação à língua geral tupi, devido à priorização da língua geral tupi pelos jesuítas e a prováveis antigos conflitos linguísticos anteriores à chegada dos portugueses. ${ }^{12}$ Segundo Elia, até "os negros recém-importados [sic] compreendiam e falavam, não o português, mas a língua geral. Aliás, a sua condição de escravos identificavaos com as massas aborígines, a quem estava confiado esse papel." (ELIA, S. Op.Cit., p.77)

\section{Nos tumbeiros, havia também línguas!}

As línguas atingidas pelo tráfico negreiro em direção ao Brasil provinham de duas áreas do continente africano: a área oeste-africana, correspondente a territórios situados ao norte do Equador, e a centro-africana, atuais Congo, Angola e Moçambique. Entre as línguas da área oeste-africana que migraram forçadamente para a colônia brasileira, estavam línguas iorubás [conhecidas no Brasil como nagô], fula, uolofe, mandinga, bambara, haussá, etc. ${ }^{13}$ Sobretudo as línguas do subgrupo banto foram faladas pela maioria da escravatura do Brasil chegada da África Central atingida pelo tráfico negreiro. Em relação às línguas oeste-africanas importadas no Brasil, os falares do subgrupo banto eram tipologicamente mais homogêneos e em número mais reduzido. Entre eles, as línguas quimbundo, congo e umbundo foram particularmente significativas (BONVINI, p.26 et seq.).

Durante grande parte do tráfico transatlântico, entre a captura-compra do cativo no interior da África e a chegada ao porto-entreposto de embarque, podia se passar um período de tempo relativamente longo, durante o qual cativos, comumente de diversas proveniências, seguiam juntos a caminho do litoral, geralmente atados pelo pescoço com o libambo. A permanência nos portos, fortes, entrepostos, etc. podia também alongar-se por diversos meses. ${ }^{14}$ Segundo Bonvini,

Essa organização particular do tráfico, orientado para o mercado brasileiro, criou as condições lingüísticas favoráveis à emergência de uma nova situação lingüística [...] (caracterizada) por uma concentração forçada e prolongada de falantes de línguas africanas diferentes, mas tipologicamente próximas, o que pôde conduzir, no caso de Angola, à adoção do quimbundo como língua veicular. (BONVINI, Op.Cit. p.32).

Os capturados tiveram igualmente um contato prolongado com o português, eventualmente usado, no interior, por recrutadores de cativos - pumbeiros, em Angola - e certamente falado, nos portos, pelos negreiros brasileiros e, não raro, em certas regiões, de outras nacionalidades. $\mathrm{O}$ mesmo tipo de contato com o português ou outras línguas prolongava-se nos navios, durante a macabra travessia. (Ibidem). Uma vez

\footnotetext{
${ }^{12}$ Ver ELIA, S. Op. Cit., p.177 \& SILVA NETO, S. da. Op. Cit., p.59.

${ }^{13}$ No Brasil, também grafado hauçá.

${ }^{14}$ Cf., entre outros: MEILLASSOUX, C. L'esclavage en Afríque précoloniale. Dix-sept études presentées par. Paris: Maspero, 1975; MEILlASSOUX, C. Mulheres, celeiros \& capitais. Trad. A. Figueiredo. Porto: Afrontamento, 1977; MEIRS, S. \& KOPYTOFF, I. (Eds.) SIavery in África. Historical and anthropological perspectives. USA: University of Wisconsin Press, 1979; MENDES, L.A. de O. Memória a respeito dos escravos e tráfico da escravatura entre a costa d'África e o Brazil. Apresentado à Real Academia das Ciências de Lisboa. (1793). Porto: Escorpião, 1977.
} 
chegados nos seus lugares de cativeiro e trabalho forçado, onde, é bom lembrar, por razões óbvias, os "escravistas preocupavam-se em formar seus plantéis com escravos das mais diversas culturas e línguas africanas", o destino linguístico dos cativos dependeu de inúmeras variáveis. (MAESTRI, Op. Cit, p.81). Contudo, é indiscutível que um considerável número de línguas africanas foram praticadas no Brasil. Na sua famosa obra A influência africana no português do Brasil, de 1948, Renato Mendonça lembra termos provas de que

foram faladas no Brasil as seguintes línguas: nagô ou ioruba, quimbundo, gêge ou ewe, kanuri ou nifê, e guruncis. Provas estas que constam de vocabulários dessas línguas, coligidos pessoalmente por Nina Rodrigues e outros. Destas se salientaram duas que foram adoptadas pelos negros no país, como línguas gerais: o nagô ou ioruba na Baía e o quimbundo no Norte e no Sul. (MENDONÇA, 1948, p.87-88).

Para apresentar as diversas línguas e coinés africanas dominantes no Brasil, Bonvini utiliza uma divisão correspondente à produção escravista, periodizada em função dos seus produtos de exportação dominantes. Nessa visão por ciclos de produtos produzidos, para o século 17, ele identifica o quimbundo como língua africana mais falada na colônia luso-americana. Na opinião de Bonvini, o quimbundo gramatizado pelo padre jesuíta Pedro Dias, em 1697, em Arte da lingoa de Angola, oferecida a Virgem Senhora N. do Rosario, Mãy, e Senhora dos mesmos Pretos, seria muito próximo do atualmente falado em Angola, não se tratando de um pidgin ou de outra língua mista. Era "falada por escravos originários de Angola, numa área geográfica extensa, não limitada apenas ao estado [sic] da Bahia", mas amplamente praticada também em Pernambuco, no Recife e no Rio de Janeiro, manifestando "assim seu papel de língua veicular, adquirido já em Luanda".(BONVINI, Op.Cit., p.33 et seq.)

\section{A língua de Palmares}

O fato da gramática da língua quimbundo do padre Pedro Dias, publicada em 1697, que atesta a prática generalizada desta língua em boa parte do Brasil setecentista, ter sido redigida na época da destruição da confederação dos quilombos de Palmares, em 1695, parece confirmar a tese que o quimbundo possa ter sido dominante naqueles mocambos. Acredita-se que os quilombos de Palmares teriam chegado a contar com entre seis e dez mil habitantes. ${ }^{15}$

Em Palmares: a guerra dos escravos, Décio Freitas lança a hipótese de que os quilombolas não poderiam ter adotado "sem desastroso sacrifício da unidade, uma das línguas nativas da África. Necessitavam de uma linguagem comum. Assim foi como se elaborou a linguagem palmarina: um sincretismo lingüístico, em que os elementos africanos tiveram ascendente decisivo, mas que incorporava, por igual, elementos do português e do tupi" (FREITAS, D. Op.Cit. p.41-43). Freitas apóia-se para tal tese no comentário que o governador Francisco de Brito Freire sobre os mocambeiros: "Falam uma língua toda sua, às vezes parecendo da Guiné ou de Angola, outras parecendo português e tupi, mas não é nenhuma dessas e sim outra língua nova." (Ibidem)

Serafim da Silva Neto, ao contrário, considera que Palmares constituiu "um exemplo típico da coexistência de três civilizações: a branca, a negra e a índia"(FREITAS, D. Op.Cit. p.41-43). Para ele, os palmarinos eram provavelmente bilíngues, falando um crioulo português e um idioma africano, certamente do grupo banto, já que a maioria dos quilombolas era originária de Angola, chegando a ser chamado o quilombo de Palmares de Angola janga (Angola pequena). A favor da tese do uso da língua quimbundo em Palmares, milita o fato dos principais títulos da confederação de Palmares serem de origem angolana - "nganga zumba"; "nzumbi", etc. ${ }^{16}$ Desgraçadamente, como lembra Freitas, "não restaram vestígios significativos da linguagem palmarina"(FREITAS, Ibidem). o entanto, como não foi realizada uma exploração intensiva de toda a documentação palmarina nos arquivos europeus, sobretudo holandeses, podemos esperar ainda alguma revelação nesse sentido.

Segundo Bonvini, no século 18, durante o ciclo da mineração, dentro dos limites do quadrilátero mineiro, teria sido amplamente praticada a língua mina, também conhecida como gê, ewe, jeje ou gu, que constitui uma variedade do fon, de família cuá, parte do tronco nigero-congolês (como o banto e o iorubá) (BONVINI,

\footnotetext{
${ }^{15}$ Ver, entre outros, PÉRET, B. O Quilombo dos Palmares. Organização, ensaios e estudos complementares: PONGE, R. e MAESTRI, M.. Porto Alegre: Ed. da UfRGS, 2002; ALVES FILHO, I. Memorial dos Palmares. Rio de Janeiro: Xemon, 1988; CARNEIRO, E. $O$ quilombo dos Palmares. $3^{\mathrm{a}}$ ed. Rio de Janeiro: Civilização Brasileira S. A., 1966; FREITAS, D. Palmares: a guerra dos escravos, Porto Alegre: Mercado Aberto, 1984; GOMES, Flávio. Palmares. Escravidão e liberdade no Atlântico Sul. São Paulo: Contexto, 2005.

${ }^{16}$ Ver CARBONI, F. \& MAESTRI, M. A linguagem escravizada. Língua, história, poder e luta de classes. $2^{\text {a }}$ ed. rev. e ampl. São Paulo: Expressão Popular, 2005, p.26.
} 
Op. Cit., p.39 et seq.) Essa língua foi descrita em um manual destinado aos escravocratas, para melhor lidarem com suas escravaturas, que só seria publicado em 1945 em Portugal - Obra nova da lingoa geral de mina, traduzida, ao nosso Idioma por Antonio da Costa Peixoto, Nacional do Reino de Portugal, da Provincia de Entre Douro e Minho, do concelho de Filgueiras. ${ }^{17}$

Bonvini faz notar que, para Correia Lopes, que comentou o manual, "os contemporâneos de Costa Peixoto sabiam perfeitamente que o $g u$ não era a língua materna de todos os escravos que o falavam no Brasil". Tratava-se portanto de uma língua geral, a qual Correia Lopes presume encontrar-se em estado de forte enfraquecimento e até mesmo de pidginização, em razão de seu contato com o português e por ser falada por africanos que não a tinham como língua materna (BONVINI, Op. Cit., p.39 et seq.)

Também para o século 18 e para a mineração, em aparente contradição com a indicação da dominância da língua mina defendida por Antonio da Costa Peixoto, Aires da Mata Machado Filho sublinha, em O negro e o garimpo em Minas Gerais, de 1964, uma "predominância de negros Congueses, Angoleses, Benguelas, etc." sobre possíveis indivíduos de outra procedência, entre eles, negros não bantos (DA MATA MACHADO FILHO, 1964, p.20.) A análise do vocabulário de 65 cantos de trabalho (vissungos), praticados pelos negros mineradores em São João da Chapada, levou Aires da Mata Machado a evidenciar o caráter banto da língua ali falada: "[...] alguns conhecedores da 'língua' com quem conversamos, falam em língua d'Angola e língua banguela (nunca dizem benguela), embora também se refiram ao nagô. Os textos, pela maior parte, são vazados em ambundo, mas, pelo menos em uma das canções, encontram-se termos nagô" (Id.ib. p.107).

É importante lembrar que, segundo Bonvini, no Brasil, o termo nagô é utilizado para designar falares iorubás. Isto é, línguas pertencentes ao tronco nigero-congolês e à família benuê-congolesa, mas à subfamília defóide e não à bantóide. Com seus inúmeros dialetos, o iorubá tem estatuto de língua oficial na atual Nigéria, sendo ensinada em algumas universidades. Por outro lado, o termo ambundo, utilizado por Aires da Mata, referia-se, na época a uma língua banta. Nas classificações atuais, ambundo é utilizado para indicar apenas um povo de Angola Central, correspondente ao antigo reino de Ndongo, cuja língua é o quimbundo, hoje considerada membro do subgrupo bantóide do Sul, por sua vez pertencente à subfamília bantóide, inserida na família benuê-congolesa, porção do tronco nigero-congolês.

O pesquisador mineiro vai mais longe ao sugerir que os mineradores negros de São João da Chapada praticassem um "dialeto crioulo", de caráter banto. E, para além das inúmeras controvérsias sobre a existência de um crioulo entre a escravatura do Brasil, o aspecto interessante da pesquisa de Aires da Mata é o fato de ter identificado três grupos nas cantigas da mineração: "[...] o primeiro constituído de peças em puro ambundo [sic]; o segundo, mais numeroso, com palavras nativas dos africanos, misturadas com vocábulos vernáculos; o terceiro, em puro português do Brasil"(Loc cit,) Tal realidade evidencia uma clara situação diglóssica na sociedade escravizada do Brasil.

Feitores e vigias e donos de lavras precisavam aprender a língua banguela, para entender os escravos e os fiscalizar. E é de se notar que esses, seguindo o impulso natural de que as gírias derivam, alteravam de propósito as palavras, ampliando-as ou encurtando-as. Poucos brancos em serviços só de negros esforçavam-se para entender e falar a língua dos vissungos. [...] São comuns os personativos e locativos em ambundo. E o mais eloqüente é o aparecimento de uma interjeição, de evidente origem africana, já pelas circunstâncias que cercam o seu aparecimento, já pela ocorrência do $\mathrm{r}$ brando inicial. Referimo-nos a rio-rio ( $\mathrm{r}$ brando) com que se impõe silêncio. (Id.ib. p.107 et passim)

Mais recentemente, ao se referir à língua mina descrita por Antonio da Costa Peixoto, Bonvini também sugeriu o bilinguismo de alguns trabalhadores escravizados, ao afirmar que o mina teria sido utilizado "como meio de dissimulação por muitos escravos que falariam melhor o português" (BONVINI, E. Op.Cit., p.40).

\section{Negros novos e ladinos plurilíngues}

$\mathrm{Na}$ análise histórico-linguística de Bonvini, o plurilinguismo dos trabalhadores escravizados no Brasil atingiria seu apogeu no século 19. Uma eventual explicação para tal fato seria que o tráfico negreiro conheceu um vigor jamais visto logo após a sua proibição ao norte do equador, em 1815, e, sobretudo, após a sua interdição formal, em 1831, introduzindo no Brasil abundantes levas de africanos, em geral jovens, provenientes de diversas regiões da África. ${ }^{18}$ Por outro lado, a extinção definitiva do tráfico transatlântico, em

\footnotetext{
${ }^{17}$ Desdobramos as abreviações

${ }^{18}$ Ver CONRAD, R.E. Tumbeiros: o tráfico de escravos para o Brasil. São Paulo: Brasiliense, 1985; MARQUES, J.P. Os sons do silêncio: o Portugal de oitocentos e a abolição do tráfico de escravos. Lisboa: Imprensa de Ciências Sociais, 1999; Organon, Porto Alegre, $\mathrm{n}^{\circ}$ 47, julho-dezembro, 2009, p.85 -1 27
} 
1850, determinou numerosas deslocações de trabalhadores dentro do próprio território brasileiro, das zonas agora menos produtivas do Nordeste para a região sudeste e as lavouras de café, favorecendo inúmeros contatos linguísticos. ${ }^{19}$

Foi precisamente nesta época que Nina Rodrigues (1862-1906) debruçou-se sobre a população negra no Brasil e sobre as línguas dos "colonos pretos", após lembrar a aflição de Sílvio Romero, autor de um "pequeno vocabulário de termos africanos" dos "negros cabindas", devido ao fato de "que no Brasil se houvesse descurado completamente do estudo das línguas africanas faladas pelos escravos pretos" e que os intelectuais brasileiros estivessem "levianamente deixando morrer os nossos negros da Costa como inúteis" e abandonando "o estudo de tantos dialetos africanos que se falam em nossa senzala" (RODRIGUES, 1977, p.122).

Nina Rodrigues reiterou a visão que duas línguas africanas foram certamente adotadas como línguas gerais no Brasil: "[...] a nagô ou iorubá na Bahia, a quimbunda ou congolesa no norte e no sul." (Id.ib., p.129 et seq.)Entre as línguas sudanesas possivelmente importadas no Brasil, Nina Rodrigues propõe distinguir aquelas sobre as quais se tinha indício certo - isto é, que "deixaram da sua existência vestígios positivos em documentos conhecidos" ou que eram usadas pelos "africanos [então] sobreviventes" - das línguas "cuja existência apenas pode ser admitida como corolário de terem vindo ao Brasil, como escravos, negros daqueles países em que elas são faladas na África".

No primeiro grupo, o pesquisador e médico maranhense radicado na Bahia coloca seis línguas: o nagôiorubá, a língua jeje, o haussá, o kanúri, a língua tapa, a língua dos negros gurúnces, conhecidos na Bahia como negros galinhas. Nina Rodrigues supôs que muitas outras línguas sudanesas teriam sido faladas no Brasil, sem que se possa "dar disso uma prova tão positiva": seria o caso das línguas minas, do mandinga (falado na Guiné portuguesa) e das línguas fulá. Enfim, referiu-se às inúmeras línguas bantas, que foram "faladas extensamente no Brasil pelos escravos negros" (RODRIGUES, Op.Cit., p.147 et seq). Segundo o autor, na Bahia, no início do século 20, o nagô ainda era praticado, sendo chamado língua da costa.

É interessante registrar que não se encontra mais em uso a categoria "sudanesa" utilizada na época de Nina Rodrigues para designar línguas africanas. Com ela, Nina Rodrigues referia-se às línguas faladas na área correspondente à faixa sudanesa, que se estende do litoral atlântico ao mar Vermelho e tem como fronteiras, ao norte, o Sahel e, ao sul, a floresta equatorial. Entre as línguas citadas por Nina Rodrigues como sudanesas, algumas são hoje consideradas pertencentes ao tronco nigero-congolês: é o caso das línguas nagô-iorubá (da família benuê-congolesa e subfamília defóide); do jeje ou mina (família cuá e subfamília fon); do gurúnsi (família gur) e da língua tapa, muito próxima do iorubá. Outras, como o haussá, que conta hoje com mais de cinquenta milhões de falantes, é visto atualmente como parte do tronco afro-asiático e da família chadiana. Quanto à língua canúri, ela é hoje considerada como parte do tronco nilo-saariano. ${ }^{20}$

Concluiremos as presentes considerações sobre o caráter plurilíngue do Brasil histórico com as reflexões do sociólogo pernambucano Gilberto Freyre. Ao abordar o trabalhador escravizado do século 19 a partir dos jornais brasileiros da época, ele registrou que a pluriétnica e pluriclassista formação social brasileira deixara necessariamente suas marcas no fluxo ininterrupto da língua portuguesa falada e escrita deste lado do Atlântico:

Anúncios já cheios de palavras de origem africana ou tupi-guarani; de brasileirismos do melhor sabor - sapiranga, cassaco, cambiteiro, aça ou assa, xexéu, troncho, perequeté, mulambo, munganga, cambado, zambo, cangulo, tacheiro, engurujado, banguê, banzeiro, batuque, munheca, batucar.

Nos anúncios das gazetas que nossos bisavôs liam pacatamente à luz da vela ou de candeeiro, já se escrevia como se falava: já se escrevia português brasileiramente. Compara-se a língua dos anúncios de 1825 com a dos discursos dos constituintes do Império, ainda rançosa de casticismo: são duas línguas inimigas. E, no mesmo jornal, a frase dos artigos políticos e literários com a dos anúncios: a superioridade de força e, direi mesmo, de beleza de expressão dos anúncios é enorme. [...] A língua dos anúncios de jornais brasileiros do tempo do Reino e da época do Império parece-me às vezes maior, como expressão nacional, do que toda a nossa literatura do mesmo período. (FREYRE, 1979, p.7).

\section{A CONSTRUÇÃO DO UNITARISMO LINGUÍSTICO NO BRASIL}

\footnotetext{
RODRIGUES, Jaime. De costa a costa. Escravos, marinheiros e intermediários do tráfico negreiro de Angola ao Rio de Janeiro (1780-1860). São Paulo: Cia das Letras, 2005.

${ }^{19}$ Ver VIOTTI DA COSTA, E. Da senzala à colônia. 3 ed. São Paulo: Brasiliense, 1989; CONRAD, R.E. Tumbeiros. Op. Cit. ${ }^{20}$ Ver BONVINI, E. Op.Cit., p.30 et seq. 
Em alguns casos, a construção das línguas nacionais, intimamente ligada à codificação formal e à elaboração das idéias sobre estas mesmas línguas, deixou um espaço mais ou menos importante às variantes locais e sociais e até mesmo a outras línguas presentes no território. Esse não foi o caso do Brasil. A história linguística do Brasil Colonial iniciou com uma ampliação do uso de uma língua que, em Portugal, já estava em processo de construção. Ou seja, que conhecia processo de gramatização e de normatização que objetivavam atingir um mínimo de variação formal, e uma ampla legitimação e difusão, para expansão do seu valor funcional.

É também importante lembrar que, para impor sua língua a todo o território, a elite galêgo-portuguesa teve que expulsar, literalmente, os muçulmanos em direção ao sul, num processo que durou cerca de duzentos anos e que ficou conhecido como Reconquista, termo claramente marcado de desvio ibérico-centrista. Nas regiões central e meridional do território português, o centralismo linguístico do Norte teve que estabelecer relações de 'compromisso', 'absorvimento' e 'intercâmbio' com vozes estrangeiras: dos árabes ou mouros, dos moçárabes e dos hebreus, entre outros (TEYSSIER, 1987, p.6).

Como vimos, no Brasil, o português, com suas variantes regionais e sociais, também herdadas de Portugal, teve que conviver com outras forças linguísticas centrífugas, constituídas das línguas nativas, de ao menos - duas línguas gerais tupis e de inúmeras línguas africanas, inclusive, segundo afirmam os especialistas, duas línguas gerais - a nagô-iorubá, na Bahia, e a quimbundo, no Norte e em todo o Sul, como apenas assinalado. Nas palavras de Serafim da Silva Neto, "no início da colonização, quando os portugueses eram apenas um punhado de aventureiros em meio das hordas bárbaras [sic], houve um período de bilingüidade." (DA SILVA NETO, Op.Cit., p.71).

Em certas regiões do Brasil, o retrocesso da língua geral tupi, que, como vimos, em alguns momentos e em certas situações de fala, dominou o repertório linguístico, deveu-se a diversos fatores, ao menos no que diz respeito à língua geral paulista, já que, no Maranhão, esta língua conheceu vida ainda mais longa. O principal fator de retrocesso da língua geral tupi parece ter sido a chegada multitudinária de trabalhadores escravizados africanos e de suas línguas, desde meados do século 16. Igualmente, o grande número de portugueses que afluíram atraídos pela descoberta das minas de ouro, no final do século 17, e o processo de urbanização ensejado pela mineração, durante todo o século 18 , teriam contribuído para este enfraquecimento e para o fortalecimento do português em certas regiões do Brasil, com destaque para as áreas mineradoras.

A gramática de Antonio da Costa Peixoto e a pesquisa de Aires da Mata, que abordamos anteriormente, registram a presença maciça de línguas africanas e do português e fenômenos de convergência e mescla entre essas línguas. Em 1808, a transferência para o Rio de Janeiro da Família Real, da corte e de enorme parte do aparato administrativo português - umas quinze mil pessoais -; o fim do regime colonial, devido a essa transferência; a difusão mesmo limitada de livros, jornais, etc.; uma vida cultural mais substancial, etc. certamente melhoraram a posição do português no repertório linguístico da população do Brasil.

Ao longo dos séculos, foi sobretudo uma política linguística lusófila, centralizadora e repressora, subreptícia ou explícita, ditada pelo desprezo das classes dominantes portuguesas e brasileiras para com os setores subalternizados da população que favoreceu o predomínio do português, na sua variedade padronizada. Antes mesmo das medidas linguísticas impostas pelo marquês de Pombal, já se registravam práticas glotocidas prevendo o uso obrigatório da língua portuguesa no Brasil e a repressão a práticas aloglotas, em especial às línguas gerais tupis. Segundo Serafim da Silva Neto, o "governo metropolitano jamais se descuidara da difusão da língua portuguesa, eficiente fator de assimilação." (Id.ib. p.75) Serafim da Silva Neto assinala a carta enviada, em 1701, por El-Rei, ao governador-geral do Brasil, "recomendando aos missionários que 'se esforçassem por ensinar aos índios na língua portuguesa'." (Loc.it.) Em 1730, João de Maia da Gama, governador do Maranhão, recomendava que "aos pequenos, e já aldeados, façam falar português uns com os outros, e dar-lhe alguma palmatoada, quando os ouvir falar pela língua [deles]" (Id.ib. pp. 73-74). A política de Pombal não permaneceu lettre morte, sendo aplicada com zelo pelas autoridades das capitanias. Mas, é claro, foi sobretudo após a Independência, em 1822, e, principalmente, depois da proclamação da República, em 1889, e mais especificamente a partir dos anos 1930 e da ditadura de Getúlio Vargas [Estado Novo], que as políticas linguísticas centralizadoras e glotocidas seriam mais eficientes. ${ }^{21}$

Paradoxalmente, à primeira vista, para as autoridades estatais portuguesas e, a seguir, brasileiras, a discriminação das línguas dos trabalhadores escravizados africanos e afro-descendentes não parece ter sido uma preocupação, ao menos se comparado ao esforço realizado para reprimir os inúmeros falares dos nativos

\footnotetext{
${ }^{21}$ Ver CARONE, E. A República Nova (1930-1937). São Paulo: DIFEL. 1982; FAUSTO, B. A revolução de 1930. Historiografia e história. 6 ed. São Paulo: Brasiliense, 1979; FONSECA, P.C.D. Vargas: o capitalismo em construção. 1906-1954. São Paulo: Brasiliense, 1989; SGANZERLA, C.M. A lei do silêncio: repressão e nacionalização do Estado Novo em Guaporé (1937-1945). Passo Fundo: UPF, 2001.
} 
e, sobretudo, as línguas gerais tupis. De fato, a literatura ficcional e científica dos séculos 19 e 20 está cheia de alusões e comentários alarmistas e preconceituosos sobre a ação deteriorante que a presença de tantos africanos tinha sobre a língua portuguesa, sobretudo dos cativos domésticos sobre as formas de falar das casas-grandes. ${ }^{22}$ Entretanto, faltam registros históricos a respeito de medidas oficiais, semelhantes à proibição pombalina, direcionadas especificamente à repressão das línguas africanas amplamente faladas no Brasil, como vimos, ao menos enquanto continuaram a chegar, até 1850, milhões de africanos e africanas com suas línguas.

Uma explicação para esse fenômeno - que estudos mais aprofundados precisariam comprovar - seria que as comunidades americanas eram donas da terra antes da chegada dos portugueses e, apesar destes, bem ou mal, conservaram um mínimo de sua organização social, ao menos em algumas regiões não diretamente atingidas pela colonização. Prova disto é que, hoje, a mais de duzentos anos das medidas pombalinas, ainda existem, no Brasil, comunidades falando línguas nativas, ainda que em situações diglóssicas muito mais favoráveis ao português. O fato de não serem os trabalhadores escravizados considerados parte da comunidade nacional, mesmo após a Independência, em 1822, pode eventualmente ter contribuído para a despreocupação das autoridades com suas línguas.

Contudo, a principal explicação parece ser que, para deixar os cativos africanos e seus descendentes sem voz, não foi preciso prever uma política e planificação linguísticas, pois as próprias forças imanentes ao escravismo colonial encarregaram-se de destruir as línguas à medida que aniquilavam tendencialmente os seres humanos cativos, cultural e materialmente. Multidões de africanos escravizados, arrancados de suas múltiplas formações sociais originárias, entravam incessantemente no Brasil, em processo de ininterrupta aniquilação-substituição tendencial. ${ }^{23}$ Eram inseridos coercitivamente em um sistema de produção onde eram a principal força de trabalho, o principal capital produtivo e propriedades de seus exploradores. Sistema no qual o cativo "funcionava, em certas ocasiões, como dinheiro em sentido estrito, como meio de troca ou meio de circulação"(GORENDER, Op.Cit., p.175)..

Em outras palavras, foram reduzidos, ainda que apenas metafórica, legal e formalmente, à situação de coisas, de bem objetivo, operação social que ensejava a privação de direitos essenciais enquanto seres humanos e sociais (Id.ib. p.49). Seus escravizadores os concebiam essencialmente como máquinas de trabalho, para quem a comunicação social - e, portanto, verbal - seria em boa parte supérflua, criando hiatos e fraturas no mais íntimo da comunicação das comunidades dos produtores diretos, no seu pensamento, na sua psique, naquilo que Volochinov chama de linguagem interior(BACHTIN, Op.Cit., p.114 et seq.).

\section{Destruição espontânea, lenta e gradual}

Para a Sociolinguística, a categoria repertório linguístico refere-se ao conjunto dos recursos linguageiros línguas, dialetos, variedades de línguas - à disposição e normalmente utilizados pelos membros de uma comunidade (GUMPERZ, 1971, p.182). O repertório linguístico não representa uma simples justaposição das línguas faladas pelos indivíduos desta comunidade. Trata-se de uma categoria sócial e linguística profundamente dialética, da qual fazem parte, por um lado, as relações entre os diferentes sistemas linguísticos e, portanto, suas eventuais interferências - code-switching, convergência, nivelação, etc. -, por outro, seus respectivos estatuto e valor funcional e, portanto, seu prestígio, e igualmente as representações a que estes códigos estão associados, em uma determinada formação social e em um determinado contexto histórico. ( BERRUTO, 1995, p.73 et passim.). Enquanto categoria de análise, composta de inúmeras dimensões - linguísticas, sociais, ideológicas -, apesar de redutivo, o repertório linguístico pode ajudar a enxergar a transformação dramática que a escravidão determinou para multidões de homens e mulheres, em termos de comunicação verbal, de identidade lingüística e, até mesmo, de linguagem interior, onde, com a escravidão, a maioria dos "pontos de vista sólidos e estáveis desagregaram-se"(BACHTIN, Op.Cit., p.126).

Os negro-africanos, homens e mulheres, sobretudo jovens e adultos, que os portugueses aprisionaram no Continente Negro, a partir de 1444, conheciam um nível social e econômico bastante diferenciado, devendose distinguir entre os povos que já conheciam divisão de classes e Estados complexos e as sociedades aldeãs e domésticas. ${ }^{24}$ Predominantemente, os negro-africanos estavam inseridos, territorial, econômica, cultural,

\footnotetext{
${ }^{22}$ Ver, entre outros, ELIA, S. Op.Cit.; DA SILVA NETO, S. Op.Cit.; FREYRE, G. Sobrados e mucambos Rio de Janeiro: Record, 1996.

${ }^{23}$ Cf. MARQUES, J.P. Op.Cit.; CONRAD, R.E. Tumbeiros. Op.Cit.; FIORENTINO, M. Em costas negras: Um estudo sobre o tráfico atlântico de escravos para o porto do RJ. c. 1790 c. 1830. Rio de Janeiro: Arquivo Nacional, 1995; SALVADOR, J.G. Os magnatas do tráfico negreiro: séculos XVI e XVII. São Paulo: Pioneira, 1981; UNESCO, Documentos de trabalho e relatórios da reunião de peritos. $O$ tráfico de escravos negros nos séculos XV ao XIX. Port-au-Prince, Haiti: Edições 70, 31 de janeiro a 4 de fevereiro de 1978.

${ }^{24}$ Cf. MEILlASSOUX, Claude. L'esclavage en Afríque précoloniale. Op.Cit.; MEIRS, Suzanne \& KOPYTOFF, Igor. (Eds.) Op.Cit.. Organon, Porto Alegre, $n^{\circ}$ 47, julho-dezembro, 2009, p.85-1 27
} 
ideológica e linguisticamente, em comunidades aldeãs caracterizadas por relações de produção definidas como domésticas, "formadas por uma ou mais famílias ampliadas, ou seja, pelo grupo social [aldeão] constituído pelo patriarca, por suas esposas, descendentes e agregados", praticando a divisão sexual do trabalho e vivendo da caça, da pesca, da agricultura ou do pastoreio(MAESTRI, M. Op.Cit. 1994, p.38; MEILLASSOUX, Op.Cit.).

A situação linguística da África, ainda hoje tão rica e complexa, permite pensar que muitos dos indivíduos capturados em aldeias do Sudão Ocidental, do golfo da Guiné ou da África Central conhecessem tradicionalmente repertórios linguísticos extremamente intricados, com diversas línguas - da mãe e eventualmente das outras esposas do pai, do próprio pai, do agregado da família, que como as esposas podia ser de outra aldeia ou região, a língua veicular regional, coinés de uso ainda mais amplo, língua sacra e até mesmo formas pidginizadas das línguas dos colonizadores, etc.

Cada uma destas línguas tinha seu estatuto, seu valor funcional, seu prestígio, correspondentes a uma específica organização social e a determinadas necessidades de comunicação, na família celular, na família ampliada, na comunidade aldeã, no trabalho agrícola, no mercado, nas relações com o poder, nas práticas religiosas, etc. Para aqueles seres humanos, cada uma daquelas línguas dava lugar a determinadas representações e materializava-se em discursos externos e internos com os quais iam construindo-se suas consciências, enquanto parte da ideologia social.

Para milhões daqueles seres humanos, "arrancados do meio social originário e convertidos à força em indivíduos dessocializados", a escravidão pôs fim a esta organização sócio-linguageira. A primeira ação linguística do escravizador português e, a seguir, brasileiro, foi taxonômica. Tratou-se, nas palavras de Calvet, da "dimensão linguística do direito de se apropriar" (CALVET, 2002, p.82). Antes do serem embarcados nos tumbeiros, ainda nas costas da África, os cativos perdiam seus nomes para receber pré-nomes portugueses aleatórios e repetitivos, além de serem, não raro, ferrados, antes do embarque na África e na chegada no Brasil, com sinete em brasa, com a marca do proprietário ou comerciante.

Outra estratégia dos escravizadores americanos foi privilegiar eitos étnico-linguisticamente heterogêneos, dentro das possibilidades permitidas pelo tráfico. E isso, certamente, não com o objetivo humanitário de favorecer o lusofonização dos africanos, mas para evitar que seres de mesma origem e mesma fala pudessem melhor organizar-se e resistir à sua condição de cativo.

É crível que a escravidão urbana, com destaque para certas formas da produção - negros de ganho, de aluguel, cativos domésticos, etc. - tenham favorecido as relações sociais, dando lugar a maiores oportunidades para os trabalhadores de se congregar a outros cativos ou libertos de mesma origem, ou que praticassem as mesmas línguas africanas ou, o mais provável, as mesmas línguas gerais. ${ }^{25}$

Ao contrário, a prática de privilegiar eitos pluriétnicos e plurilíngues foi dominante na escravidão rural, majoritária na vida econômica do Brasil colonial e imperial, na produção de açúcar, de minérios, de algodão, de charque, de café, etc. Tal fenômeno é tangível nas anotações das nacionalidades de africanos escravizados que o historiador rio-grandense Setembrino Dal Bosco encontrou nos inventários post-mortem de fazendas de Rio Pardo, nos anos 1819-1846: Benguelas, 28; Angolas, 11; da Costa, 35; Congos, 20; Minas, 18; Guinés, 9; Rebolos, 10; Moçambiques, 13; Monjolos, 5; Cassangas, 4; Calungas, 4; Nagôs, 3. Se à essa dispersão tendencial, acrescentamos o fato que os eitos nas fazendas pastoris, muito isoladas, eram pequenos, uns três a quatro cativos por légua quadrada, podemos dimensionar o isolamento linguístico-cultural de parte considerável dos africanos introduzidos nessa região. ${ }^{26}$

Porém, é preciso insistir no fato de que os escravizadores eram obrigados, quando adquiriam cativos, a se subordinarem às ofertas do tráfico negreiro, o que privilegiava regiões e nacionalidades africanas como sementeiras de cativos, com importantes variações através dos anos. Esse fenômeno foi registrado pelo levantamento da nacionalidade de africanos arrolados em inventários post-mortem de charqueadores pelotenses, nos anos 1858-1887, pelo historiador rio-grandense Euzébio Assumpção. ${ }^{27}$

\section{Origem de Africanos nas Charqueadas Pelotenses - 1858-1887}

\footnotetext{
${ }^{25}$ Ver, entre outros, KARASCH, M.C. A vida dos escravos no Rio de Janeiro (1080-1850). São Paulo: Companhia das Letras, 2000; ZANETTI, V. Calabouço urbano: escravos e libertos em Porto Alegre (1840 - 1860). Passo Fundo: UPF, 2002; SIMÃO, A.R.F. Resistência $e$ acomodação: a escravidão urbana em Pelotas (1822-1850). Passo Fundo: UPF Editora, 2002; ALGRANTI, L.M. $O$ feitor ausente. Estudo sobre a escravidão urbana no Rio de Janeiro. 1808-1822. Petrópolis: Vozes, 1988.

${ }^{26}$ DAL BOSCO, Setembrino. A fazenda pastoril no Rio Grande do Sul. 17889-1888. Programa de Pós-Graduação em História, Universidade de Passo Fundo, 2008. (Dissertação de mestrado)

${ }^{27}$ ASSUMPÇÃO, J.E. "Pelotas: escravidão e charqueadas. (1780-1888)" Porto Alegre: PUC, 1994, p.149-155. (Dissertação de mestrado).
} 


\begin{tabular}{|c|c|c|c|c|}
\hline & 1780-1831 & 1831-1850 & $1850-1888$ & Total \\
\hline ANGICO & - & - & 01 & 01 \\
\hline ANGOLAS & 16 & 01 & 11 & 28 \\
\hline BENGALAS & 02 & 01 & 05 & 08 \\
\hline BENGUELAS & 23 & - & 06 & 29 \\
\hline BUJIMINS & - & - & 02 & 02 \\
\hline BUNDA & - & - & 01 & 01 \\
\hline CABARE & - & - & 01 & 01 \\
\hline CABINDAS & 07 & 01 & 08 & 16 \\
\hline CABO VERDES & - & - & 02 & 02 \\
\hline CABUNDAS & 02 & - & - & 02 \\
\hline CAÇANJES & 04 & - & - & 04 \\
\hline CALABARES & 01 & - & 02 & 02 \\
\hline CAMEGERONES & - & - & 01 & 01 \\
\hline CAMUNDAS & 02 & - & 02 & 02 \\
\hline CATUMINA & 01 & - & - & 01 \\
\hline CATURRAS & - & - & 02 & 02 \\
\hline CONGOS & 30 & 04 & 07 & 41 \\
\hline CORANGE & 01 & - & - & 01 \\
\hline GABOA & 01 & - & - & 01 \\
\hline GAMBA & - & - & 01 & 01 \\
\hline GUANGUILAS & 02 & - & - & 02 \\
\hline GUIANA & 01 & - & - & 01 \\
\hline GUICAMAS & 05 & - & - & 05 \\
\hline HANCAS & 01 & - & - & 01 \\
\hline MANJUBES & 02 & - & 01 & 03 \\
\hline MINAS & 22 & - & 98 & 120 \\
\hline MOÇAMBIQUES & 05 & - & 31 & 36 \\
\hline MONJOLOS & 14 & - & 05 & 19 \\
\hline NAGÔS & - & 06 & 16 & 22 \\
\hline REBOLOS & 23 & - & - & 23 \\
\hline SÃO TOMÉ & - & - & 01 & 01 \\
\hline SONGA & 01 & - & - & 01 \\
\hline
\end{tabular}

Nas senzalas plurilíngues de muitas unidades produtivas escravistas, inúmeros fenômenos linguísticos podem ter surgido: convergência e coineização entre línguas africanas afins; enfraquecimento de alguns falares e fortalecimento de outros, com o surgimento de línguas gerais; code-switching, etc. Parece também indiscutível que os cativos assenzalados tiveram que aprender português, com toda a probabilidade de modo aproximativo e passivo, no geral e tendencialmente dentro do domínio restrito da produção e atividades específicas em que eram produtores, fazendo brotar formas linguageiras que as ciências da linguagem costumam qualificar pejorativamente de crioulos.

Do mesmo modo que a legislação pombalina não resultou na lusofonização das comunidades indígenas por ela afetadas, mas, ao contrário, à sua tendencial marginalização linguística, a situação social de absoluta dominação em que os cativos encontravam-se não autoriza a pensar que seu aportuguesamento tenha se dado 
da forma harmoniosa e voluntária, tal como o discurso dominante tende a propor. Nesse sentido, Silvio Elia afirma que os próprios africanos não demonstrariam "muito interesse em preservar suas falas tribais [sic]; através da língua portuguesa simplificada e, de certo modo, por eles reinterpretada, é que se comunicavam com os seus 'donos', com suas iaiás, com seus patrõezinhos"(ELIA, S. Op.Cit., p.144). Aliás, segundo o mesmo autor, constitui a melhor prova disto o fato que "o maior escritor brasileiro, Machado de Assis" era um "mulato" como "todos" nós sabemos! (Loc.cit.)

Faz igualmente parte desta visão geral a proposta que, ao chegar da África, "esses negros já falavam, certamente, um dialeto crioulo-português pois a nossa língua foi geral nas costas da África durante os séculos XV, XVI e XVII." (DA SILVA NETO, Op.Cit., p.42). Essa é também a opinião do grande linguista brasileiro Antônio Houaiss: "A proveniência dessas peças [sic - africanos de São Tomé e da Guiné] deve ser posta em relevo, pois muitas [sic] já estavam afeitas aos portugueses, com os quais já se comunicavam na língua franca da costa oriental africana - de base portuguesa - já em português mesmo, ainda que português para fins práticos elementares" (HOUAISS, 1992, p.76). Sílvio Elia chega, no entanto, a ultrapassar tal visão idealistico-voluntarista, intuindo que os "negros, pouco a pouco, foram esquecendo seus falares nativos, que se iam tornando desnecessários." (Ibid., p.145).

\section{Repertórios linguisticos empobrecidos}

O plurilinguismo que tendia a caracterizar o repertório linguístico dos setores sociais escravizados no Brasil explica-se mais pelo fator quantitativo que constituía a constante chegada de milhões de cativos novos, locutores de inúmeros dialetos e línguas do continente africano, durante mais de trezentos anos, do que por fatores ideológicos ou de suposta consciência ou semi-consciência dos africanos sobre a necessidade de manter suas línguas originárias. Se isto pode ter acontecido, como vimos, em situações marginais - na escravidão urbana, em quilombos, etc. - o exame das condições gerais de existência da maioria dos trabalhadores escravizados nas cidades e nos campos permite trabalhar com a hipótese de que não houve esta consciência. O próprio plurilinguismo do qual falamos só pode ter sido extremamente dissimétrico e, paradoxalmente, empobrecedor para aqueles locutores à margem da vida e da comunicação social qualificadora, como veremos a seguir.

As línguas, dialetos e variedades de língua que formam os repertórios linguísticos de populações envolvidas em processos migratórios tendem a perder completamente o estatuto que tem no país de origem, isto é, suas características geopolíticas, socio-demográficas, em suma, suas potencialidades de utilização. Esses códigos linguísticos pertencentes ao repertório original dos migrantes também tendem a reduzir fortemente seu valor funcional, já que deixam de ser utilizáveis em grande parte dos domínios da nova formação social. Contudo, comunidades migrantes podem tentar preservar suas línguas, reconstituindo na nova terra alguns destes domínios comunicativos. No seio da família, em associações étnicas ou de classe, nas equipes de trabalho, entre amigos, em jornais e programas de rádio, etc., os imigrantes podem continuar vinculando a comunicação e a circulação de idéias às línguas de origem.

E o aspecto linguístico mais interessante na maioria dos fenômenos migratórios é que, progressivamente, à medida que se enfraquecem as línguas de origem, os repertórios linguísticos dos migrantes e de seus descendentes tendem a se enriquecer da língua vernácula do país ou região hóspede, com suas eventuais variações. Esta língua, através das novas gerações escolarizadas, acaba geralmente sendo a primeira língua falada até mesmo no pólo mais gregário da comunicação, que é a família. Com ela, ao lado das perdas e das rupturas linguageiras que a imigração implica, os imigrantes, na primeira geração e, sobretudo, nas sucessivas, tem a possibilidade de ampliar seus universos semânticos e suas redes linguístico-identitárias, graças à sua inserção complexa na nova formação social e em função dos papéis que nela desenvolvem (CARBONI, 2002, p.235 et passim.).

No regime escravocrata brasileiro, os trabalhadores escravizados não puderam manter ou reconstituir domínios comunicativos, onde continuar usando suas línguas. Não puderam nem mesmo transmitir estes falares a seus filhos no seio do domínio familiar. De fato, para além das polêmicas de que o tema da família escrava/escravizada é objeto na historiografia brasileira, a documentação aponta para a tendência do escravizador a dificultar ao cativo o acesso à família. Família entendida como comunidade com um mínimo de estabilidade temporal, espacial e social, com possibilidade de coabitação, por um período significativo, em espaço comum, com relacionamento e capacidade de tomada de decisões.

A família, nos fatos, constitui tradicionalmente o lócus privilegiado de sobrevivência, por séculos, das línguas, dos discursos e das tradições minoritárias e discriminadas diante das pressões linguísticas e ideológicas externas. Os segmentos historiográficos que defendem-sugerem crescentemente a tese da existência de relações familiares estáveis como fenômeno geral da escravidão brasileira não parecem perceber

Organon, Porto Alegre, no 47, julho-dezembro, 2009, p.85-1 27 
a contradição desta proposta, diante do literal glotocídio assinalado no que se refere aos falares africanos, mesmo dominantes.

Rapidamente, no Brasil, os cativos africanos e afro-descendentes viram as possibilidades de uso de suas línguas ou do que delas sobrou restringirem-se sobretudo a domínios não coloquiais da linguagem, literalmente congelados por sua função simbólica, rítmica, etc. como a religião, os cantos de trabalho, os cantos de lazer, etc. Contudo, contrariamente aos imigrantes europeus, os cativos, em geral, não puderam incluir o português no seu repertório linguístico, ao menos não de forma plena, enquanto instrumento de comunicação com todos os setores da sociedade e em todos os domínios enunciativos. Ou seja, enquanto instrumento ideológico capaz de processar pensamento lógico, complexo, racional, instrumento necessário para estabelecer crescentemente uma relação a menos alienada possível com o mundo, para poder agir sobre ele. São quase desconhecidas expressões literárias, poéticas, pictóricas, etc. da população escravizada, submetida fortemente a uma produção duramente alienada e alienante. Tal pobreza foi igualmente produto da política de silenciamento já referida.

Nos anúncios de cativos fugidos, são comuns os registros de africanos e crioulos escapados que gaguejavam ou falavam com dificuldade o português, registro do caráter precário e traumático do aprendizado dessa língua. Em $O$ escravo nos anúncios de jornais brasileiros do século XIX, Gilberto Freyre comenta essa triste realidade, explicando-a em parte, numa visão preconceituosa, como resultado de uma baixa vocação ao aprendizado de línguas de alguns africanos!

A gagueira de vários dos gagos que passam pelos anúncios de negros fugidos nos jornais brasileiros do tempo do Império talvez resultasse de experiências extremas de medo ou de pavor de crianças ainda inermes [...]. A 'fala atrapalhada' [...] podia [...] (nascer) da dificuldade experimentada por alguns escravos, africanos natos, de ouvido menos agudo, em aprenderem a língua portuguesa. (FREYRE, Op.Cit., p.61).

A dicotomia heteroglossia - heterologia que os soviéticos Jakubinskij e Bakhtin cunharam para se referir à diferença entre uma situação meramente plurilíngue, onde coexistem diversos dialetos, e a convivência de diversos discursos sociais, dentro de uma mesma língua nacional parece adequada para descrever a situação plurilingue que o Brasil escravista conheceu. ${ }^{28}$ Situação com centenas de línguas, dialetos, falares, coinés coexistindo, sem que, no entanto, milhões de indivíduos falantes destas línguas pudessem fazer ouvir socialmente suas vozes. Paradoxalmente, o heteroglossia presente na população escravizada, com seu caráter extremamente limitado, dispersivo e empobrecedor, impediu tendencialmente que houvesse um mínimo de heterologia. Até porque a heterologia só pode ser dialogizada e, em um aparente paradoxo, isto só é possível quando há uma língua comum ou uma possibilidade e uma vontade de um intercompreensão.

Idealmente, o processo histórico que provoca a unificação da língua deveria levar a uma diferenciação sócio-funcional e ideológica, devendo, como já dito, garantir um máximo de compreensão mútua, em todos os domínios da vida material, social e ideológica. Isto pode soar como heresia, mas, idealmente, para os trabalhadores escravizados novos e ladinos, uma política linguística lusófila, explicitamente glotocida em relação às línguas africanas e, sobretudo, eficaz, permitindo que eles adquirissem uma verdadeira competência comunicativa em português, teria sido mais salutar do que o abandono linguistico-discursivo em que foram deixados, desprovidos de meios complexos de expressão.

\section{CONCLUSÃO}

Ao mesmo tempo em que era considerado e tratado como propriedade, o trabalhador escravizado também era visto como ser humano, com um corpo, uma subjetividade, aptidões intelectuais, fraquezas, etc. Era sobretudo considerado essencialmente humano, já que possuía, como atributo central, sua capacidade de trabalhar, capacidade que só os seres humanos possuem. Nas palavras de Jacob Gorender, tal contradição

foi manifestada e desenvolvida pelos próprios escravos, enquanto indivíduos concretos, porque, se a sociedade os coisificou, nunca pôde suprimir neles ao menos o resíduo último de pessoa humana. Antes que os costumes, a moral, o direito e a filosofia reconhecessem a contradição [entre a redução formal à coisa e a essência humana do

\footnotetext{
${ }^{28}$ Ver BRANDIST, C. Bakhtine, la sociologie du langage et le roman. In Le discours sur la langue en URSS à l'époque stalinienne (épistémologie, philosophie, idéologie). Cahiers de l'ILSL, n.14, 2003, p.71-72 e BAKHTINE, M. Esthétique et théorie du roman, Op. Cit., p.96. Segundo Brandist, a importância desta distinção entre heteroglossia e heterologia foi neutralizada pela tendência de traduzir as duas palavras raznojazyčie e raznorečie por heteroglossia ou plurilinguismo.

Organon, Porto Alegre, n 47, julho-dezembro, 2009, p.85-1 27
} 
cativo] e se preocupassem com resolvê-la [...], antes disso os próprios escravos exteriorizaram sua condição antagônica, na medida em que reagiram ao tratamento de coisas. (GORENDER, Op.Cit., p.49).

Diante das reações dos cativos à sua escravização, os escravocratas responderam também de forma contraditória, negando a redução absoluta e ideal do trabalhador à objeto e reconhecendo-lhes a condição de seres humanos completos, com plena consciência e responsabilidade por seus atos. Assim fez o proprietário, no direito privado, quando interpretou a resistência passiva do cativo ao trabalho escravizado como indolência, preguiça, mau caráter, isto é, características humanas, e o castigava por isso. Foi assim também com o direito público que reconhecia a responsabilidade penal dos cativos, em caso de crimes cometidos contra os escravizadores, fugas, rebeliões, etc.

A enorme documentação judiciária referente à escravidão, depositada nos arquivos brasileiros, é certamente uma das fontes essenciais para a procura da voz dos africanos e afro-descendentes escravizados, apesar de essa documentação ter sido produzida a partir de inúmeros filtros que buscavam, consciente ou inconscientemente, silenciar as razões de tais atos e os sentimentos profundos dos interrogados. Além do desequilíbrio inerente a qualquer interação verbal entre sujeitos sociais tão desiguais como os escravizadores e os escravizados, ainda mais num contexto como o judicial, as declarações dos supostos infratores foram normalmente deturpadas por interrogadores e escrivões, que as traduziam e interpretavam.

Entretanto, ao tentarem defender-se, de modo hábil ou inábil, para escapar das severas penas reservadas aos insubmissos à exploração, os trabalhadores escravizados deixaram incrustados nesses documentos, ainda que muitas vezes em forma quase imperceptível, traços essenciais de suas falas e visões de mundo. Basta saber encontrar, nas transcrições daqueles depoimentos, as "falhas, fissuras, recobrimentos e outros incidentes discursivos através dos quais os discursos manifestam o que eles procuram velar: sua heterogeneidade constitutiva" (GARDIN, , 2005).

Outra importante fonte para a recuperação da voz-consciência dos trabalhadores escravizados são os relatos de cativos e ex-cativos sobre o cativeiro. Infelizmente, contrariamente aos Estados Unidos e ao Caribe, onde são abundantes, tais depoimentos são extremamente raros no Brasil, onde os trabalhadores escravizados permaneceram maciçamente analfabetos e os cientistas sociais despreocuparam-se olimpicamente em registrar a memória dos últimos ex-cativos (MAESTRI, 1988, p.9). Até mesmo Gilberto Freyre, que nos seus monumentais trabalhos sobre a escravidão, Casa-grande \& senzala e Sobrados e mucambos, de inícios dos anos 1930, explorou criativa e pioneiramente inúmeras fontes antes ignoradas, despreocupou-se, sintomaticamente, com o depoimento direto dos milhares de ex-cativos que, na época, certamente ainda viviam(FREYRE, 2003; FREYRE, 1996).

Tais depoimentos não constituem uma leitura transparente e essencial da escravidão, mas nos permitiriam entrever na própria alienação ensejada pela ordem escravista nos escravizados, um processo fundamental na constituição das visões de mundo das classes subalternizadas no Brasil de hoje. Maria Benedita da Rocha, a Maria Chatinha, ex-cativa, entrevistada em 1981, pelo padre Luciano Penido, até o fim de sua vida, acreditou na eficácia do castigo físico, excelente remédio contra a delinquência. ${ }^{29}$ Outro ex-trabalhador escravizado, Mariano dos Santos, no seu depoimento refere-se diversas vezes, de modo aparentemente alienado, à caridade de Dão Pedrinho Segundo e da Princesa Isabel. ${ }^{30}$

Outro aspecto interessante, que uma primeira análise das duas entrevistas apenas citadas permite evidenciar, é a utilização reiterada pelos dois ex-cativos entrevistados da palavra libertação para se referir ao que a sociedade dominante denominou abolição. A aparente ausência deste termo no universo semântico daqueles ex-cativos é reveladora da sua carga semântica vinculada à visão dos escravizadores.

Enfim, entre os possíveis documentos onde encontrar vestígios da voz dos cativos, estão os cantos de trabalho, que acompanhavam e davam a cadência aos gestos coletivos de trabalho, comuns a muitas sociedades camponesas. No livro Os sons dos negros no Brasil, de 2008, José Ramos Tinhorão faz notar que, ao serem escravizados e transportados para o Brasil, vendo romper-se os laços, sobretudo familiares, em que se baseava sua estrutura de vida comunitária na África, os cativos teriam adaptado seus cantos propiciatórios e

\footnotetext{
${ }^{29}$ Publicada sob os cuidados de Mário Maestri na revista CIÊNCIA E CULTURA, da SBPC (São Paulo, maio de 1985, pp.828-34); em 1986, na revista QUADERNI DI STORIA (Bari, Itália, pp. 152-73) e, enfim, no livro Depoimentos de escravos brasileiros, São Paulo: Ícone, 1988.

${ }^{30}$ Entrevista realizada por aluno do Grupo de Estudo sobre a História Social da Escravidão, da UFRJ, sob a coordenação do professor Mário Maestri, publicada na revista HISTÓRIA EM CADERNOS, Rio de Janeiro, 1: 3-18, jan/jul 1983, reeditada a seguir na revista HISTÓRIA: QUESTÕES \& DEBATES, Curitiba, 4(6): 81-97, jan.1983, e no livro Depoimentos de escravos brasileiros, São Paulo: Ícone, 1988 .
} 
de trabalho, onde se referiam ao bem-estar de suas famílias após a colheita, por exemplo. Para Tinhorão, os trabalhadores escravizados

passaram a usar os versos de seus cantos para conversar entre si enquanto trabalhavam, o que descobriram ser possível fazer através não apenas do emprego de seu quase dialeto, composto pela mistura de português com palavras africanas, mas da inteligente ocultação do sentido do que diziam pelo jogo metafórico das imagens. (TINHORÃO, 2008, p.125).

Fundamento era o nome que os africanos escravizados davam à chave para decifrar esses duplos sentidos embutidos nos seus cantos de quotidiano protesto, códigos que continuaram sendo cultivados no período pósAbolição. Num dos vissungos dos garimpeiros de Minas Gerais, registrados e estudados por Aires da Mata e retomado por Tinhorão, os trabalhadores queixam-se da dureza do trabalho que deles era exigido, e registram sinteticamente e simbolicamente que até a morte seria mais doce que aquela vida infernal do cativeiro:

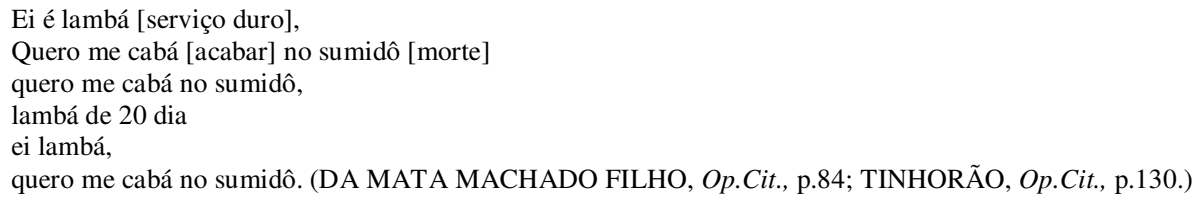

\section{Bibliografia}

ALGRANTI, L.M. O feitor ausente. Estudo sobre a escravidão urbana no Rio de Janeiro. 1808-1822. Petrópolis: Vozes, 1988.

ALVES FILHO, I. Memorial dos Palmares. Rio de Janeiro: Xemon, 1988.

ASSUMPÇÃO, J.E. "Pelotas: escravidão e charqueadas. (1780-1888)" Porto Alegre: PUC, 1994.

BACHTIN, M., M. Linguaggio e scrittura, Roma: Meltemi, 2003.

BAKHTINE, M. Esthétique et théorie du roman. Paris: Gallimard, 1978.

BERRUTO, G. Fondamenti di sociolinguistica. Roma : Laterza. 1995.

BONVINI, E. Línguas africanas e português falado no Brasil. In: FIORIN, J.L. \& PETTER, M. África no Brasil. A formação da língua portuguesa. São Paulo: Contexto, p.26 et seq.

BORGES, L.C. \& HORTA NUNES, J. La langue générale et la grammatisation des langues indiennes. In L'hyperlangue brésilienne. LANGAGES, Revue trimestrielle, n. ${ }^{\circ}$ 130, France, Larousse, juin 1998.

BRANDIST, C. Bakhtine, la sociologie du langage et le roman. In Le discours sur la langue en URSS à l'époque stalinienne (épistémologie, philosophie, idéologie). Cahiers de l'ILSL, n.14, 2003, p.71-72.

CALVET, L.-J. Linguistique et colonialisme. Petit traité de glottophagie. Paris: Payot: 2002, p.82.

CARBONI, F. Eppur si parlano. Etude diachronique d'un cas de contact linguistique dans le Rio Grande do Sul [Brésil]. Passo Fundo: EdUPF, 2002, P.235 et passim..

CARBONI, F. \& MAESTRI, M. A linguagem escravizada. Língua, história, poder e luta de classes. $2^{\mathrm{a}}$ ed. rev. e ampl. São Paulo: Expressão Popular, 2005.

CARDOSO, C.F. El modo de producción esclavista colonial en América. In ASSADOURIAN, C.S. et al. Modos de producción en América Latina. Buenos Aires: Siglo XXI, 1973.

CARNEIRO, É. O quilombo dos Palmares. $3^{\text {a }}$ ed. Rio de Janeiro: Civilização Brasileira S. A., 1966.

CARONE, E. A República Nova (1930-1937). São Paulo: DIFEL. 1982.

CONRAD, R.E. Tumbeiros: o tráfico de escravos para o Brasil. São Paulo: Brasiliense, 1985.

DA MATA MACHADO FILHO, A. O negro e o garimpo em Minas Gerais. Rio de Janeiro: Civilização brasileira, 1964.

DA SILVA NETO, S. Introdução ao estudo da língua portuguesa no Brasil. Rio de Janeiro: Departamento de Imprensa Nacional, 1951

DAL BOSCO, S. A fazenda pastoril no Rio Grande do Sul. 17889-1888. Programa de Pós-Graduação em História, Universidade de Passo Fundo, 2008. (dissertação de mestrado)

ELIA, S. A unidade lingüística do Brasil: condicionamentos geoeconômicos. Rio de Janeiro: Padrão, 1979.

FAUSTO, B. A revolução de 1930. Historiografia e história. $6^{a}$ ed. São Paulo: Brasiliense, 1979.

FIORENTINO, M. Em costas negras: Um estudo sobre o tráfico atlântico de escravos para o porto do RJ. c. 1790 c. 1830. Rio de Janeiro: Arquivo Nacional, 1995.

FONSECA, P.C.D. Vargas: o capitalismo em construção. 1906-1954. São Paulo: Brasiliense, 1989.

Organon, Porto Alegre, no 47, julho-dezembro, 2009, p.85-1 27 
FREITAS, D. Palmares: a guerra dos escravos, Porto Alegre: Mercado Aberto, 1984.

FREYRE, G. O escravo nos anúncios de jornais brasileiros do século XIX. São Paulo: Ed. Nacional, 1979. FREYRE, G. Sobrados e mucambos Rio de Janeiro: Record, 1996.

FREYRE, G. Casa grande e senzala. Formação da família brasileira sobre o regime da economia patriarcal. $47^{\mathrm{a}}$ edição revista. São Paulo: Global, 2003.

GARDIN, B. Langage et luttes sociales. Limoges: Editions Lambert-Lucas, 2005.

GORENDER, J. A escravidão reabilitada. São Paulo: Ática, 1990.

GORENDER, J. O escravismo colonial. $4^{\text {a }}$ ed. rev. e ampl. São Paulo: Ática, 1985

GUMPERZ, J.J. Language in social groups. Stanford : Stanford University Press. 1971.

HOUAISS, A. O português no Brasil. $3^{\text {a }}$ ed,. Rio de Janeiro: Revan, 1992, p.76.

KARASCH, M.C. A vida dos escravos no Rio de Janeiro (1080-1850). São Paulo: Companhia das Letras, 2000

LEMOS, C.A.C. A casa brasileira. São Paulo: Contexto, 1989.

MAESTRI, M. A pedagogia do medo: disciplina, aprendizado e trabalho na escravidão brasileira. História e memórias da educação no Brasil. Séc. XVI-XVIII. Petrópolis: Vozes; 2004. vol. 1, PP. 192-209.

MAESTRI, M. A aldeia ausente. Índios, caboclos, cativos, quilombolas, moradores e imigrantes na formação da classe camponesa brasileira. In: STEDILE, J. [Org]. A questão agrária no Brasil. São Paulo: Expressão Popular, 2005, v.2.

MAESTRI, M. Breve história da escravidão. Porto Alegre: Mercado Aberto, 1986.

MAESTRI, M. Depoimentos de escravos brasileiros.São Paulo: Ícone, 1988.

MAESTRI, M. L'esclavage au Brésil. Paris: Karthala, 1991.

MARIANI, B. Colonização lingüística. Línguas, política e religião no Brasil (séculos XVI a XVIII) e nos Estados Unidos da América (século XVIII). Campinas, SP: Pontes, 2004.

MARQUES, J.P. Os sons do silêncio: o Portugal de oitocentos e a abolição do tráfico de escravos. Lisboa: Imprensa de Ciências Sociais, 1999.

MATTOSO, K.Q. de. Ser escravo no Brasil. São Paulo: Brasiliense, 1982

MEILLASSOUX, C. L'esclavage en Afríque précoloniale. Dix-sept études presentées par. Paris: Maspero, 1975.

MEILLASSOUX, C. Mulheres, celeiros \& capitais. Trad. A. Figueiredo. Porto: Afrontamento, 1977.

MEIRS, S. \& KOPYTOFF, I. (Eds.) SIavery in África. Historical and anthropological perspectives. USA: University of Wisconsin Press, 1979.

MENDES, L.A. de O. Memória a respeito dos escravos e tráfico da escravatura entre a costa d'África e o Brazil. Apresentado à Real Academia das Ciências de Lisboa. (1793). Porto: Escorpião, 1977.

MENDONÇA, R. A influência africana no português do Brasil. Porto: Livraria Figueirinhas, 1948.

MOURA, C. História do Negro brasileiro. São Paulo: Ática, 1989.

NISKIER, A. Educação brasileira. 500 anos de história. 1500-2000. São Paulo: Melhoramentos, 1989.

PÉRET, B. O Quilombo dos Palmares. Organização, ensaios e estudos complementares: PONGE, R. e MAESTRI, M.. Porto Alegre: Ed. da UFRGS, 2002.

PONZIO, A. Tra semiotica e letteratura. Introduzione di Michail Bachtin. Milano: Bompiani, 2003.

QUEIROZ, S. Pé preto no barro branco. A língua dos negros da Tabatinga. Belo Horizonte: Editora UFMG, 1998.

RAEDERS, G. O conde de Gobineau no Brasil: o inimigo cordial do Brasil. Rio de Janeiro: Paz e Terra, 1988.

REIS FILHO, N.G. Quadro da arquitetura no Brasil. 6a. ed. São Paulo: Perspectiva, 1987.

RODRIGUES, N. Os africanos no Brasil. São Paulo: CEN, 1977, p.122.

SALVADOR, J.G. Os magnatas do tráfico negreiro: séculos XVI e XVII. São Paulo: Pioneira, 1981.

SCHWARCZ, L.M. O espetáculo das raças: cientistas, instituições e questões raciais no Brasil, 1870-1930. São Paulo: Companhia das Letras, 1993.

SGANZERLA, C.M. A lei do silêncio: repressão e nacionalização do Estado Novo em Guaporé (1937-1945). Passo Fundo: UPF, 2001.

SIMÃO, A.R.F. Resistência e acomodação: a escravidão urbana em Pelotas (1822-1850). Passo Fundo: UPF Editora, 2002.

SLENES, R.W. Na senzala, uma flor. Esperanças e recordações na formação da família escrava - Brasil Sudeste, século XIX, Rio de Janeiro: Nova Fronteira, 1999.

TEYSSIER, P. História da língua portuguesa. Lisboa: Sá da Costa, 1987, p.6

TINHORÃO, J.R. Os sons dos negros no Brasil. $2^{\mathrm{a}}$ ed. São Paulo: Editora 34, 2008. 
UNESCO, Documentos de trabalho e relatórios da reunião de peritos. O tráfico de escravos negros nos séculos XV ao XIX. Port-au-Prince, Haiti: Edições 70, 31 de janeiro a 4 de fevereiro de 1978.

VIOTTI DA COSTA, E. Da senzala à colônia. $3^{a}$ ed. São Paulo: Brasiliense, 1989.

ZANETTI, V. Calabouço urbano: escravos e libertos em Porto Alegre (1840 - 1860). Passo Fundo: UPF, 2002.

Organon, Porto Alegre, no 47, julho-dezembro, 2009, p.85 -1 27 